\title{
Analysis of Selected Oil Shale Samples from El-Lajjun, Central Jordan
}

\author{
Hani M. Alnawafleh1,2* Feras Y. Fraige ${ }^{1,3}$ \\ ${ }^{1}$ Faculty of Engineering, Al-Hussein Bin Talal University, Ma'an, Jordan \\ ${ }^{2}$ Faculty of Engineering, Tafila Technical University, Tafila, Jordan \\ ${ }^{3}$ Faculty of Engineering, King Saud University, Al-Muzahmiayah Branch, Riyadh, Saudi Arabia \\ Email: hanialnawafleh@ahu.edu.jo, hani1995@yahoo.com
}

Received 11 July 2015; accepted 3 September 2015; published 8 September 2015

Copyright (C) 2015 by authors and Scientific Research Publishing Inc.

This work is licensed under the Creative Commons Attribution International License (CC BY).

http://creativecommons.org/licenses/by/4.0/

(c) (i) Open Access

\begin{abstract}
The central Jordan part is rich in bituminous rocks that are known locally as oil shale (OS). These rocks were formed during the Maastrichtian-Palaeocene time. They belong to the Muwaqqar Chalk Marl formation (MCM). El-Lajjun OS deposit is located in relatively thinly populated area. This study presents the results of mineralogical, petrographical and geochemical analyses that are performed on selected surface outcrop oil shale samples from El-Lajjun area in central Jordan. Results show that El-Lajjun OS deposit is considered as a good source of OS resources since its organic matter is quite significant. The bulk rock material is made of carbonate.
\end{abstract}

\section{Keywords}

Oil Shale, Jordan, El-Lajjun, Petrography, TOC, Fissure Assay

\section{Introduction}

Oil shales are immature source rocks that have significant energy resources. They are considered as a potential deposit for hydrocarbon generation upon thermal maturation. Shale oil and gas can be generated by organic matter artificial thermal maturation [1]. Oil shales formed as early as Cambrian and continued to form in a variety of depositional environments [2]. The oil shale (OS) organic matter (OM) is mixed with varied amounts of mineral matter. The major OM fraction in the OS is the kerogen that could decompose to yield oil, gas and residual carbon through the pyrolysis process [3].

In Jordan, oil shale deposits are the main fossil fuel resource. They have widespread occurrence and good quality [4]. The most important deposits are those of the Late Cretaceous-Palaeocene. About 26 known deposits

${ }^{*}$ Corresponding author. 
of OS are present. Some of them, such as El-Lajjun OS, are large and relatively high-grade [5]. Alqudah et al. [6] reported that Jordanian oil shales were formed since Palaeozoic till Eocene, and they were deposited in various sub-basins such that of El-Lajjun in central Jordan.

Jordanian OS is typically brown, gray, or black, and consists of two parts: The first one is the inorganic part that is known as the mineral matter, this part forms the bulk of the OS rock material; The second one is the organic material (OM) which forms a minor fraction from OS rock material [7]. The sulphur content of Jordanian OS is up to 4.3\% [5] [8]. El-Lajjun OS deposit has the highest average oil content at average oil yield of about 9\% [9]. Several exploration and feasibility studies have been carried out on the Jordanian OS by the Natural Resources Authority (NRA). More attention has given to those deposits in central Jordan. This paper shows the results of characterization analyses for selected oil shale samples from El-Lajjun OS deposit in central Jordan. The results presented in this paper are part of a research project on Jordanian oil shales.

\section{Geologic Setting}

El-Lajjun oil shale is part of South Tethyan oil shale-phosphorite giant belt [10]. During the formation of oil shale, Jordan was located in an epicontinental sea [11]. Bioproductivity was enhanced by deep cold water rich in nutritants brought to the surface by upwelling currents [12] [13]. The deposition was influenced by syn-sedimentary tectonics [14] resulted in the formation of internal shelf basins structured by shallow swells [15]. The paleotopography of the depositional shelf during the OS formation became an important factor [16]. Syngenetic concentrations of OM in these restricted basins on the continental shelf resulted in OS formation [17]. The deposition oil shales have influenced by other controlling factors such as high rates of sedimentation (e.g. [8] [18]) and the influx of terrigenous material [19] (Figure 1).

The stratigraphic column of carbonate rocks of upper cretaceous to early tertiary is shown in Figure 2. Oil shale in Jordan is part of Muwaqqar Chalk Marl (MCM) formation [7]. The MCM formation consists of thick bedded chalky marl and marly limestones and locally microcrystalline limestones [20].

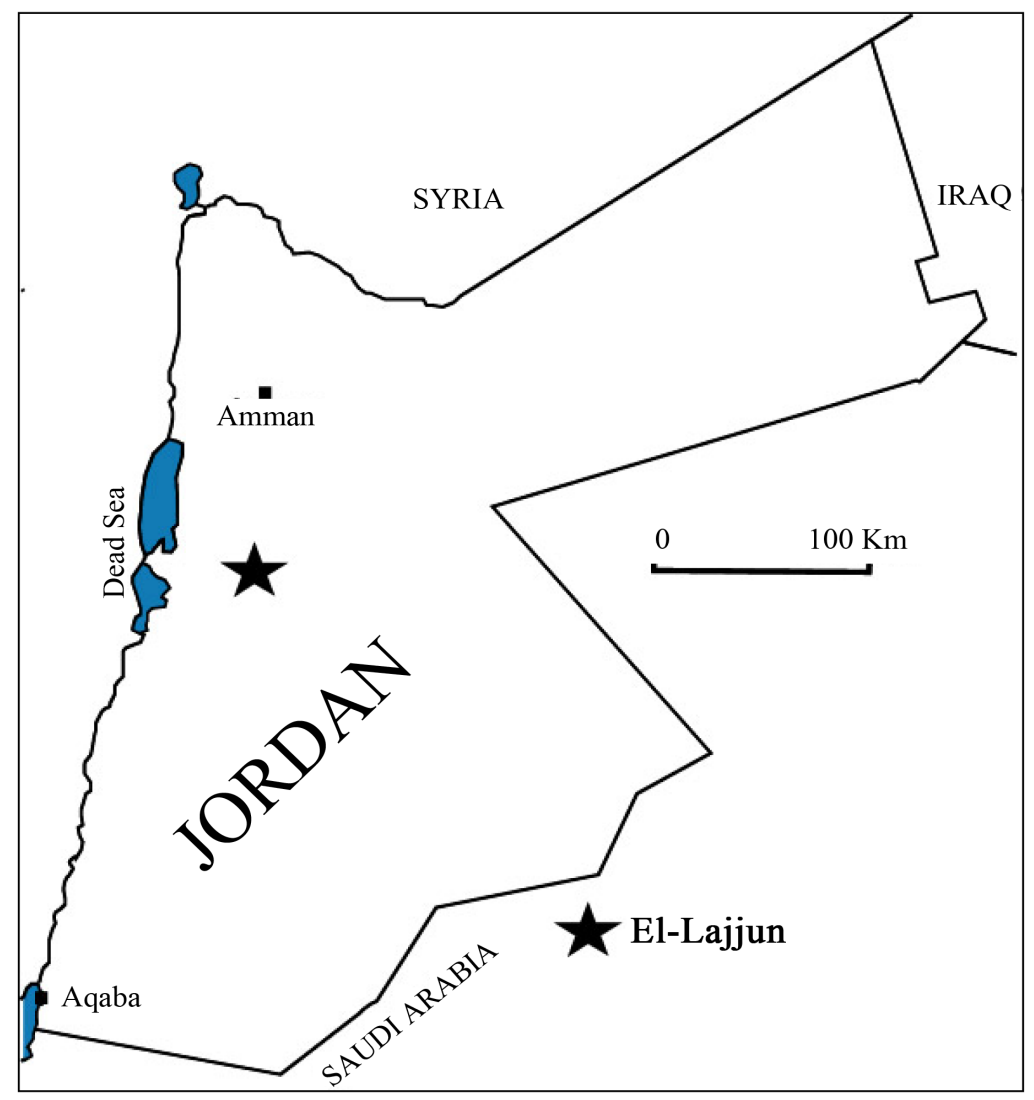

Figure 1. Map shows the relative location of El-Lajjun oil shale deposit. 


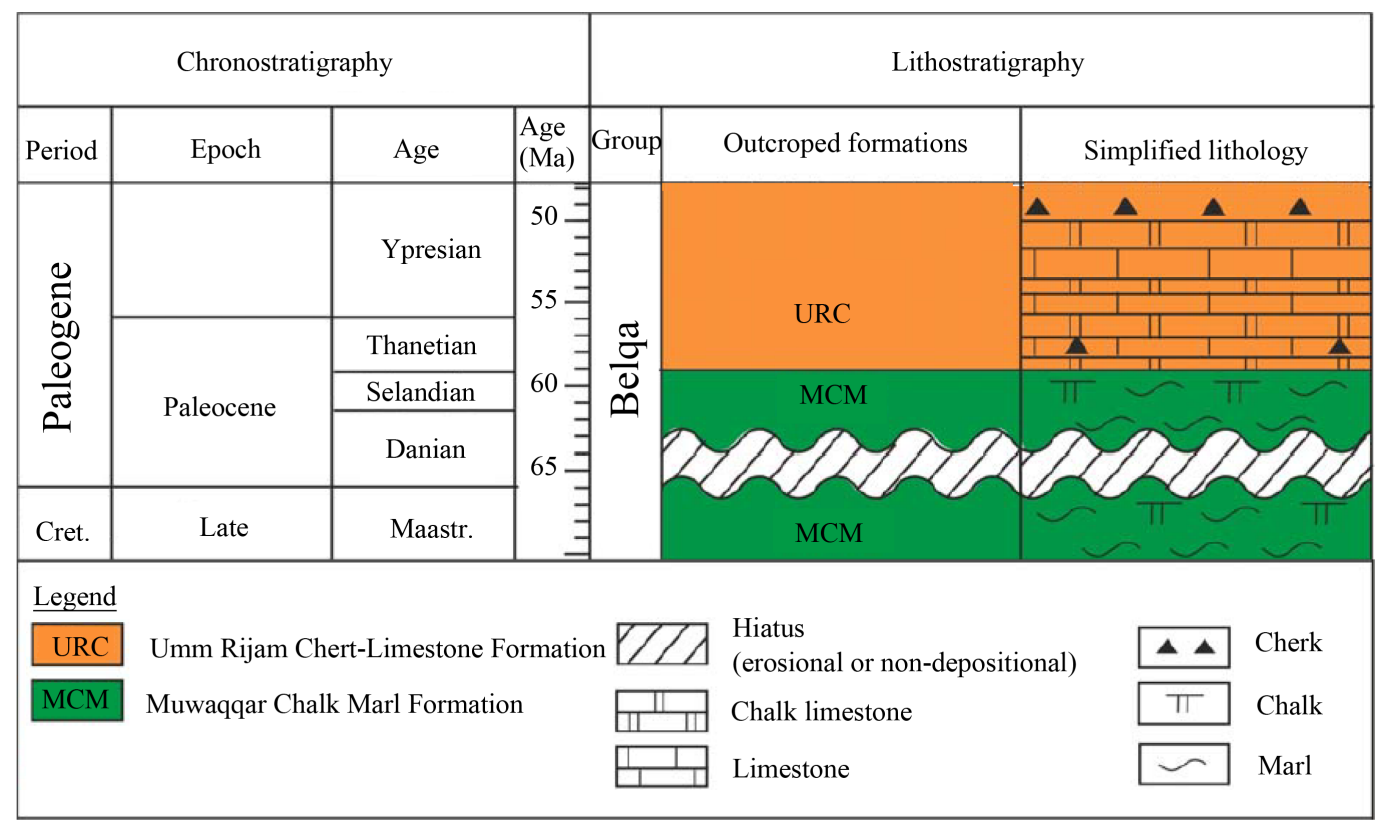

Figure 2. Lithostratigraphy of the Upper Cretaceous and Early Tertiary rocks in Jordan (Ali Hussein [21] with minor modification).

\section{Sampling and Experimental Work}

Three selected OS samples were collected from surface outcrop at El-Lajjun OS deposit (Figure 3, Table 1). The oil shales are typically brown, or black. Weathered surfaces are bluish gray. The selected fresh samples cover different rock qualities and loci within the same outcrop. Full and detailed sampling and sample preparation is reported in Alnawafleh and Fraige [4]. Sample preparation includes sample cleaning, crushing and grinding, and thin rock chips for thin section preparation.

The methodology and experimental work performed in this study is reported in Alnawafleh and Fraige [4]. For petrographic study, three thin sections were prepared and studied via the polarizing microscope and photomicrographs of each OS sample were taken using digital camera type Canon Power Shot S70. Total Organic Carbon (TOC) was determined using carbon determinator available at the Natural Resources Authority (NRA). Oil shale samples were acidified to remove inorganic carbon as $\mathrm{CO}_{2}$, and then the organic carbon combustion products of the combusted sample were catalytically converted to $\mathrm{CO}_{2}$ and measured by the carbon determinator. Around 3 grams of finely ground $(<100 \mu)$ OS were accurately weighed. About $30 \mathrm{ml}$ of $\mathrm{HCl}(20 \% \mathrm{wt})$ were slowly added to the sample and then allowed to react with boiling acid for several minutes then left to cool for room temperature. After cooling, the sample then filtered and rinsed with distilled water to remove the acid solution then allowed to dry. The weight of the dried digested sample divided by the weight of the original sample before digestion is a factor used to calculate the percentage of organic carbon (OC) after analysed by the carbon determinator as follows: \% OC $=[$ instrument reading \%/Sample wt $(\mathrm{g})] *$ Factor .

For OS mineralogical composition, the OS samples were analyzed using the XRD PHILIPS (XPERT MPD) X-ray power diffraction set with Sietronics "siehilt" automation software and Hiltonbrooks HXB data collection. Mineral identification was performed using PC-APD Diffraction software and published data. Operation and experimentation conditions are as follows: radiation: $\mathrm{Co} \mathrm{K} \alpha$., wave length 1.78896 angstrom, generation voltage is $40 \mathrm{kV}$, current $45 \mathrm{~mA}$, scanning speed $1.2^{\circ} / \mathrm{min}$, step size $0.02^{\circ}$.

Fisher assay analysis carried out via the Fisher assay apparatus available at the NRA. About 100 grams of OS powder which dried at $70^{\circ} \mathrm{C}$ for 24 hours were transferred to the retorter after cooling to the room temperature in the desiccator. After setting up the instrument, the thermal program starts up After 10 minutes. Within 60 minutes, the temperature raises up to $520^{\circ} \mathrm{C}$. The volatile organic gases that resulted from the thermal destruction of kerogen are converted to liquid by the action of the cooling unit. After cooling, the weight of the burnt sample (spent shale) is recorded. Water then separated from the liquid organic matter by addition of $100 \mathrm{ml}$ of xyelene, and upon heating water condensed and separated from oil. The weight of oil and water then recorded. Accordingly, 


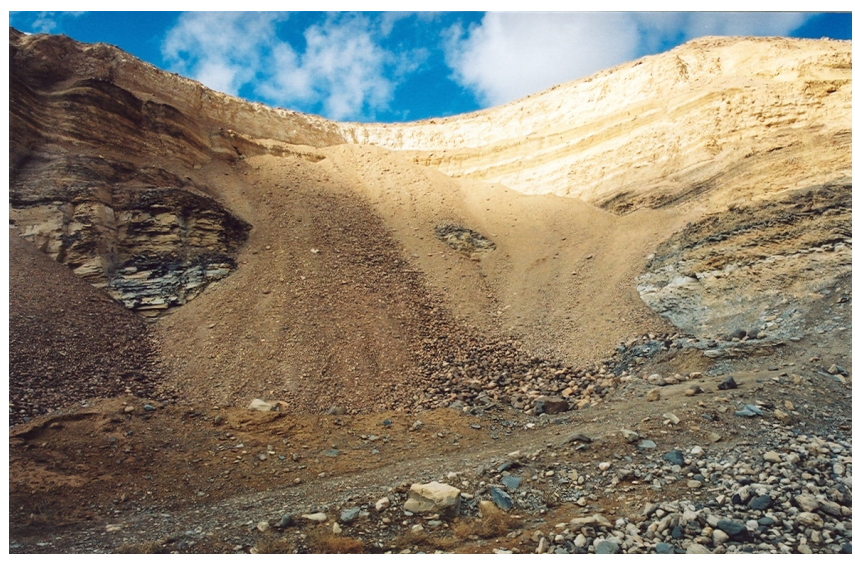

Figure 3. Generalized view (not to scale) of surface exposure at El-Lajjun oil shale deposit.

Table 1. El-Lajjun oil shale studied samples type based on field study.

\begin{tabular}{ccc}
\hline Sample NO. & Sample Type & Representative OS Part \\
\hline LOS-1 & Bituminous limestone & Lower \\
LOS-2 & Silicified Bituminous limestone & Middle \\
LOS-3 & Bituminous marl & Upper \\
\hline
\end{tabular}

the weight of volatile loss can then be determined.

\section{Results and Discussion}

\subsection{Rock Composition and Mineralogy}

The XRD results are illustrated in Table 2 and Figure 4 respectively. EL-Lajjun OS is primarily carbonate rich in organic matter. The major mineral phase is the carbonate in the form of calcite. The silicification within the middle part is confirmed from the XRD results that show majoring of calcite and quartz. Other parts have minor quartz contents. Traces of phosphate (as fluorapatite), clay as smectite and iron oxides are also present. The type of clay in bituminous rocks is affected by the depositional environment and diagenetic history [22]. El-Lajjun OS mineralogy is quite similar to other OS deposits reported from the region (e.g. [23]).

\subsection{Detail of Internal Texture}

Petrographic study results (Table 3 and Figure 5) confirm that the studied El-Lajjun OS samples are bituminous carbonate that consists of fine-grained matrix. The carbonate matrix has a flow texture and consists mainly of muddy material of cryptocrystalline micrite. Fine quartz crystals distributed in the groundmass. They may be syn-originic or post depositional materials [7]. Allochems or bioclasts are mainly foraminifera that partly invaded by organic matter. Iron oxides present as anhedral crystals of black spots. Micro-fissures are sparse, empty and show druzy texture as white calcite grew around the cavity (sample LOS-3). Brown organic matter fills pore spaces (sample LOS-1). The organic matter distribution differs from one part to another. This is related to the formational factors that control their formation during upper cretaceous [8] [24]. Rocks are rich in productivity derived material that is related to deep cold upwelling water currents at the time of OS formation [12].

\subsection{Organic Matter Content and Oil Shale Quality}

Quite high TOC values of El-Lajjun OS indicate significant content of organic matter (OM) within this deposit (Figure 6). The organic material consists largely of prebitumen bituminous ground-mass [25]. High TOC values may be due to dysoxia-anoxia (e.g. [26]) or enhanced preservation of organic matter (e.g. [27]) in addition to high productivity in surface water (e.g. [28]). As El-Lajjun is geologically considered as a local small basin during Maastrichtian (e.g. [18]), all three previous reasons must be considered. 
Table 2. The XRD analysis results of El-Lajjun oil shale samples.

\begin{tabular}{ccccccc}
\hline Location & Calcite & Quartz & Dolomite & Flour-apatite & Smectite & Hematite \\
\hline LOS-1 & $* * *$ & $* *$ & $*$ & $*$ & $*$ & $*$ \\
LOS-2 & $* * *$ & $* * *$ & $*$ & $*$ \\
LOS-3 & $* * *$ & $* *$ & $*$ & $*$ & $*$ \\
\hline
\end{tabular}

Key: Based on relative CRD high peak data. Trace: ${ }^{*}$, Minor: ${ }^{* *}$, Major: ${ }^{* * *}$.

Table 3. Petrography and internal texture of El-Lajjun oil shale samples.

\begin{tabular}{cccc}
\hline Location & Rock Name & Texture & Hardness \\
\hline LOS-1 & Foraminiferal bituminous chalky marly micrite & Cryptocrystalline and slightly flow & Soft-Medium \\
LOS-2 & Foraminiferal bituminous sandy micrite & Cryptocrystalline and flow & Very Hard \\
LOS-3 & Foraminiferal bituminous sandy micrite & Cryptocrystalline and flow & Hard \\
\hline
\end{tabular}

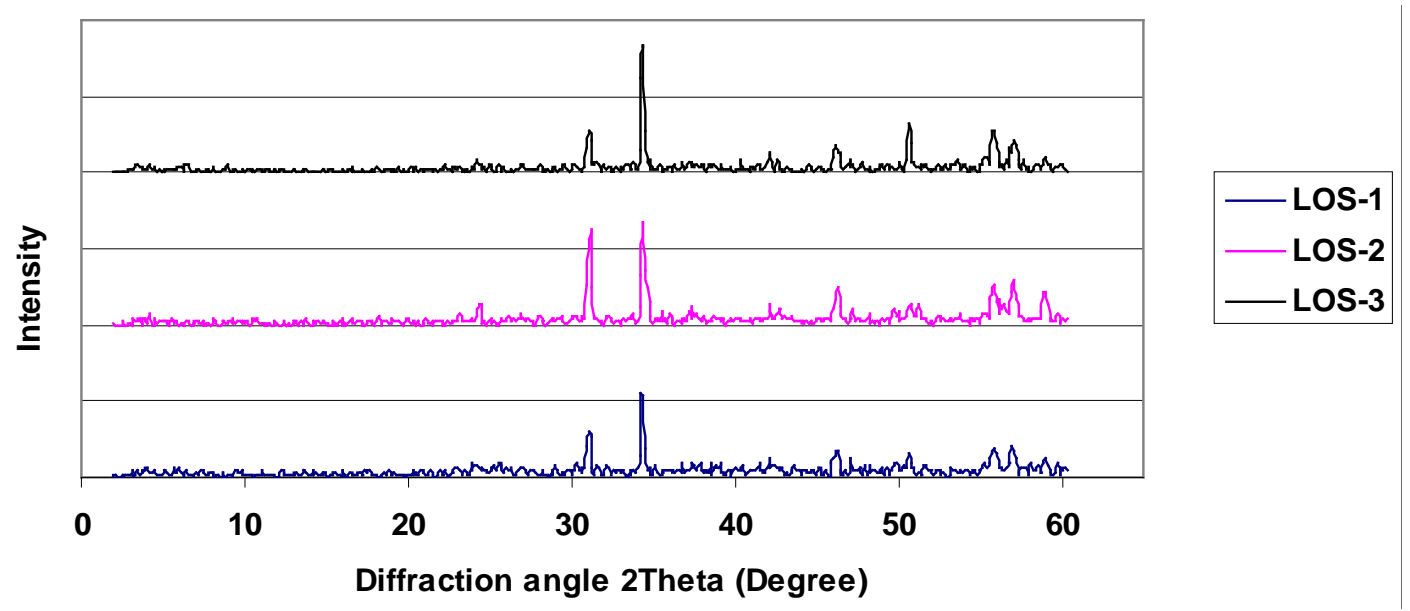

Figure 4. A series of XRD diffractograms for El-Lajjun oil shales samples.
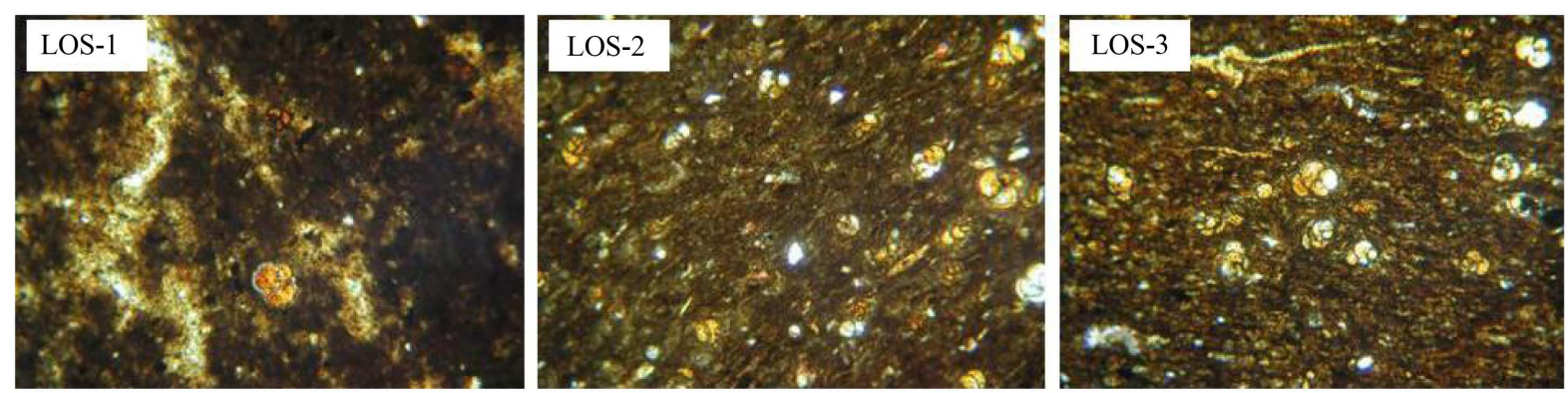

Figure 5. Photographs of El-Lajjun oil shale samples under transmitted white light microscope. Photos were taken under Plane Polarized Light (PPL) and 10x magnification.

Fisher assay analysis results are shown in Figure 7. El-Lajjun OS reveals quite similar Fisher assay results indicating similar OS quality. It has low moisture content (1.4 wt\%). This is an advantage for future OS utilization. The sulfur content has reported to be less that 5\% wt [5]. Sulphur is related to OM as well as mineral matter such as pyrite [8]. High spent shale content could be potential for cement industry in the country. EL-Lajjun OS has high average oil content and good oil yield capacity. Such high yield characteristic indicates that El-Lajjun OS is of good quality and can be considered as one of the OS potential deposits for future utilization. 


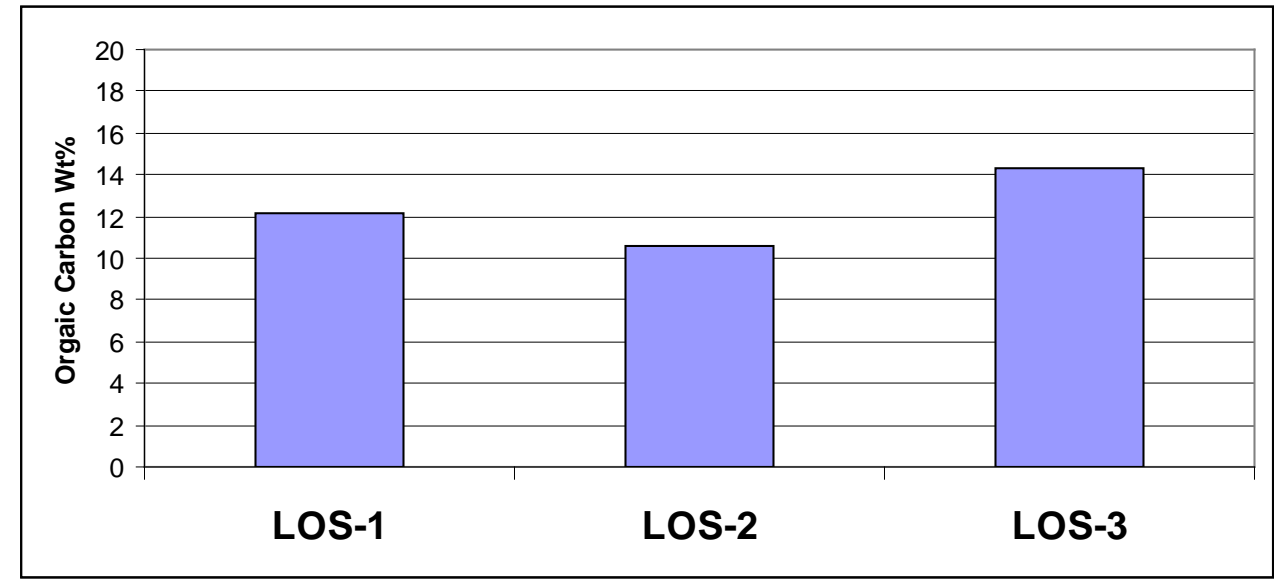

Figure 6. Total organic carbon content of the studied El-Lajjun oil shale samples.

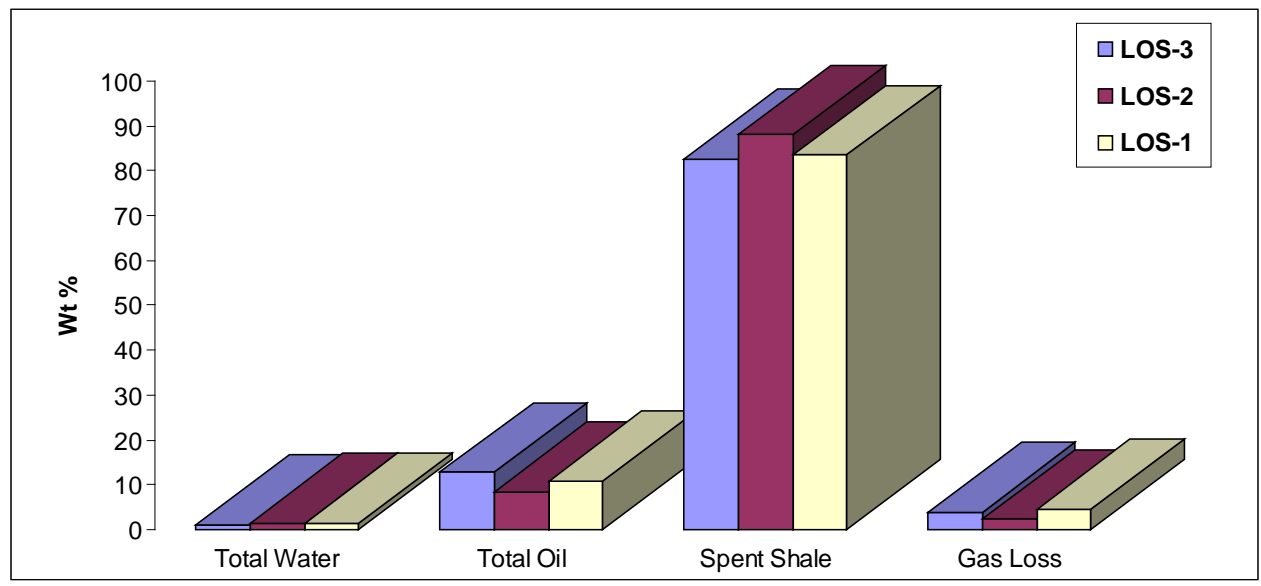

Figure 7. Fisher assay analysis results.

\section{Conclusion}

El-Lajjun oil shale in central Jordan is organic rich carbonate. The dominant carbonate mineral is calcite. Some OS bands are silicified. The rock contains traces of phosphate clay and iron oxides and is rich in foraminifera bioclasts that are partly invaded by organic matter. Clay minerals are primary smectite. EL-Lajjun OS has high average oil content and good oil yield capacity. Such high yield characteristic indicates that El-Lajjun OS is of good quality. This OS deposit is considered as one of the Jordanian OS potential deposits for future utilization.

\section{Acknowledgements}

This research project is funded by the Al-Hussein Bin Talal University (Research Fund \# 6/2009) and the Scientific Research Support Fund-Ministry of Higher Education and Scientific Research (Research Fund \# E/2/23/ 2008), Jordan. The authors are also thankful for the NRA, Jordan, for their assistance during the lab work.

\section{References}

[1] Ryan, R.C., Fowler, T.D., Beer, G.L. and Nair, V. (2010) Shell’s in Situ Conversion Process—From Laboratory to Field Pilots. In: Ogunsola, O.I., Hartstein, A.M. and Ogunsola, O., Eds., Oil Shale: A Solution to the Liquid Fuel Dilemma, ACS Symposium Series, American Chemical Society, Washington DC, 161-183.

[2] Dyni, J.R. (2003) Geology and Resources of Some World Oil-Shale Deposits. Oil Shale, 20, 193-252.

[3] Ellis, R. (2011) Oil Shale Guide. Oil Shale Information Centre, London. www.oilshale.co.uk. 
[4] Alnawafleh, H.M. and Fraige, F.Y. (2013) Characterization of South and Central Jordan Oil Shales. The European Journal of Scientific Research, 102, 589-595.

[5] Alali, J. (2006) Jordan Oil Shale, Availability, Distribution, and Investment Opportunity. International Conference on Oils Shale: “Recent Trends in Oil Shale”, Amman, 7-9 November 2006, Paper No. rtos-A117.

[6] Alqudah, M., Ali Hussein, M., Van den Boorn, S., Podlaha, O.G. and Mutterlose, J. (2015) Biostratigraphy and Depositional Setting of Maastrichtian-Eocene Oil Shales from Jordan. Marine and Petroleum Geology, 60, 87-104. http://dx.doi.org/10.1016/j.marpetgeo.2014.07.025

[7] Abed, A. and Arouri, K. (2006) Characterization and Genesis of Oil Shales from Jordan. International Conference on Oils Shale: “Recent Trends in Oil Shale”, Amman, 7-9 November 2006, Paper No. rtos-A121.

[8] Alnawafleh, H.M. (2007) Geological Factors Controlling the Variability of Maastrichtan Bituminous Rocks in Jordan. PhD Thesis, The University of Nottingham, Nottingham.

[9] Jaber, J.O., Sladek, T.A., Mernitz, S. and Tarawneh, T.M. (2008) Future Policies and Strategies for Oil Shale Development in Jordan. Jordan Journal of Mechanical and Industrial Engineering, 2, 31-44.

[10] Pufahl, P.K., Grimm, K.A., Abed, A.M. and Sadaqah, R.M.Y. (2003) Upper Cretaceous (Campanian) Phosphorites in Jordan: Implications for the Formation of a South Tethyan Phosphorite Giant. Sedimentary Geology, 161, 175-205. http://dx.doi.org/10.1016/S0037-0738(03)00070-8

[11] Camoin, G., Bellion, Y., Dercourt, J., Guiraud, R., Lucas, J., Poisson, A., Ricou, L. and Vrielynck, B. (1993) Late Maastrichtian, (69.5-65 Ma). In: Dercourt, J., Ricou, L. and Vrirlynck, B., Eds., Atlas of Tethys Palaeoenvironmental Maps, Explanatory Notes, Gauthier-Villars, Paris, 179-196.

[12] Almogi-Labin, A., Bein, A. and Sass, E. (1993) Late Cretaceous Upwelling System along the Southern Tethys Margin: Interrelationship between Productivity, Bottom Water Environments, and Organic Matter Preservation. Paleoceanography, 8, 671-690. http://dx.doi.org/10.1029/93PA02197

[13] Abed, A.M. (2013) The Eastern Mediterranean Phosphorite Giants: An Interplay between Tectonics and Upwelling. GeoArabia, 18, 67-94.

[14] Butterlin, J., Vrielynck, B., Guiraud, R., Bignot, G., Colchen, M., Clermonte, J., Andreief, P., Bellion, Y., Benkhelil, I., Cavelier, C., Cornee, J., Mercier de Lepinay, B., Montenat, C., Moreau, C., Poisson, A. and Villa, J. (1993) Lutetian, (46-40 Ma). In: Dercourt, J., Ricou, L. and Vrirlynck, B., Eds., Atlas of Tethys Palaeoenvironmental Maps. Maps, BEICIP- FRANLAB, Rueil-Malmaisson, 307 p.

[15] Powell, J. and Moh'd, B. (2011) Evolution of Cretaceous to Eocene Alluvial and Carbonate Platform Sequences in Central and South Jordan. GeoArabia, 16, 29-82.

[16] Abed, A.M. and Sadaqah, R. (1998) Role of Oyster Bioherms in the Deposition and Accumulation of Highgrade Phosphorites in Central Jordan. Journal of Sedimentary Research, 68, 1009-1020. http://dx.doi.org/10.2110/jsr.68.1009

[17] Dill, H.G., Kus, J., Abed, A., Sachsenhofer, R.F. and Abul Khair, H. (2009) Diagenetic and Epigenetic Alteration of Cretaceous to Paleogene Organic Rich Sedimentary Successions in Northwestern Jordan, Typical of the Western Margin of the Arabian Plate. GeoArabia, 14, 101-140.

[18] Abed, A.M., Arouri, K., Amiereh, B.S. and Al-Hawari, Z. (2009) Characterization and Genesis of Some Jordanian Oil Shales. Dirasat: Pure Sciences, 36, 7-17.

[19] Alqudah, M., Ali Hussein, M., Van den Boorn, S., Podlaha, O.G. and Mutterlose, J. (2014) Calcareous Nannofossils Biostratigraphy of Oil Shales from Jordan. GeoArabia, 19, 117-140.

[20] Ali Hussein, M., Alqudah, M., Van den Boorn, S., Podlaha, O.G. and Mutterlose, J. (2014) Ichnofabrics of Eocene Oil Shales from Central Jordan and Their Use in Paleoenvironmental Reconstructions. GeoArabia, 19, 143-158.

[21] Ali Hussein, M. (2013) Sedimentology of Cretaceous-Paleogene Oil Shales from Jordan. Unpublished PhD Thesis, Ruhr-Universität Bochum, Bochum.

[22] Stuben, D., Kramar, U., Berner, Z., Stinnesbeck, W., Keller, G. and Adatte, T. (2002) Trace Elements, Stable Isotopes, and Clay Mineralogy of the Elles II K-T Boundary Section in Tunisia: Indications for Sea Level Fluctuations and Primary Productivity. Palaeogeography, Palaeoclimatology, Palaeoecology, 178, 321-345. http://dx.doi.org/10.1016/S0031-0182(01)00401-1

[23] Minster, T., Yoffe, O., Nathan, Y. and Flexer, A. (1997) Geochemistry, Mineralogy and Paleoenvironments of Deposition of the Oil Shale Member in the Negev. Israel Journal of Earth Sciences, 46, 41-59.

[24] Abed, A.M. (2000) The Geology of Jordan and Its Environment and Water. Publication of the Jordanian Geologists Association, Amman (in Arabic).

[25] Hufnagel, H., Shmitz, H. and El-Kaysi, K. (1980) Investigation of the Al-Lujjun Oil Shale Deposits. BGR, Technical Cooperation Project No. 7821655, NRA and Federal Institute for Geosciences and Natural Resources, Hannover.

[26] Murphy, A.E., Sageman, B.B. and Hollander, D.J. (2000) Black Shale Deposition and Faunal Overturn in the Devonian 
Appalachian Basin: Clastic Starvation, Seasonal Water-Column Mixing, and Efficient Biolimiting Nutrient Recycling. Paleoceanography, 15, 280-291. http://dx.doi.org/10.1029/1999PA000445

[27] Stow, D.A., Huc, A.Y. and Bertrand, P. (2001) Depositional Processes of Black Shales in Deep Water. Marine and Petroleum Geology, 18, 491-498. http://dx.doi.org/10.1016/S0264-8172(01)00012-5

[28] Meyers, P.A. and Doose, H. (1999) Sources, Preservation, and Thermal Maturity of Organic Matter in Pliocene- Pleistocene Organic-Carbon-Rich Sediments of the Western Mediterranean Sea. In: Zahn, R., Comas, M.C. and Klaus, A., Eds., Proceedings of the Ocean Drilling Program, Scientific Results, Vol. 161, 383-390.

http://dx.doi.org/10.2973/odp.proc.sr.161.235.1999 